\title{
Nigeria's Oilboom Period (1973-1983): Was Agriculture Really Neglected?
}

\author{
Aliyu A. Ammani \\ Agricultural Economics, Policy and Resource Management Programme, National Agricultural Extension and \\ Research Liaison Services, Ahmadu Bello University, Zaria, Nigeria
}

\begin{abstract}
Over the years several authors have attributed the decline in Nigerian agricultural production to the neglect of the agricultural sector that resulted from the discovery of crude oil, what is known as the oilboom factor. This paper set out to find answer to the question: was agriculture really neglected as a result of the oilboom? The study took a historical perspective to trace the path of capital expenditure allocations to the agricultural sector in Nigeria. Secondary data on planned capital expenditure allocation to the agriculture sector before and during the oilboom period; and the budget estimates of capital expenditure allocations to the Agriculture, Water Resources, Health, Education and Defence sectors in Nigeria during the oil boom period 1977-1983 were sourced and used. Graphic descriptive statistics and the one-way analysis of variance technique were used to achieve the objectives of the study. The Tukey's Multiple Comparison method w as employed to determine which mean(s) differ, in both cases, in the one-way analysis of variance tests conducted. The empirical findings of the study indicate significant increase in the quantity of capital expenditure allocation to the agriculture sector during the oilboom period; and that more capital expenditure was allocated to the agriculture sector than was allocated to either of Health, Education or Defence sectors in Nigeria during the oilboom period. Thus, it concluded that the decline in agricultural production in Nigeria was, statistically, not attributable to the neglect of the agricultural sector resulting from oil boom. The reason could be as a manifestation of Dutch Disease, Natural Resource Curse, Rent Seeking phenomenom, or something else.
\end{abstract}

Keywords Oilboom, Agricultural Development, Neglect, Dutch Disease, Natural Resource Curse, Nigeria

\section{Introduction}

At Nigeria's independence in 1960, agriculture was the mainstay of the Nigerian economy. According to Ilugbuhi (1968), peasant agricultural production for export provided the stimulus to Nigeria's overall economic growth. Agriculture provided employment to over $75 \%$ of the population and accounted for over $70 \%$ of total food consumption (Reynolds, 1966). It also provided raw materials for industry, export earnings to finance imports and foreign exchange (Alamu, 1981).

At the peak of the oilboom, Abdullahi (1981) observed:

Nigeria can nolonger produce enough food for its fast growing population neither could the (then) agricultural system cope with the increasing demands of the agricultural raw materials to keep the country's oilmills, textile and other agro-based industries operating at full capacity let alone have surplusses for export. In fact many of the agro-based industries which once depended on locally produced raw materials are closing down unless of course they are allowed to import part or all of these raw materials from abroad. Numerous

* Corresponding author:

aaammani@yahoo.co.uk (Aliyu A. Ammani)

Published online at http://journal.sapub.org/statistics

Copyright (C) 2011 Scientific \& Academic Publishing. All Rights Reserved other parameters point to the obvious and undeniable fact that the country is 'progressively' becoming unable to cope with the overall needs of its food and raw materials.

Over the years several authors have attributed the decline in Nigeria's agricultural production to the neglect of the agricultural sector as a result of the oilboom (Abdullahi, 1981; Okojie, 1991; Osuntogun et al, 1997; Asiabaka and Owens, 2002; Walkenhorst, 2007; Sekumade, 2009; Chukwuemeka and Nzewi, 2011; Izuchukwu, 2011). The purpose of this paper is to debunk this view by demonstrating statiscally that agriculture was not neglected as a result of the oilboom. However the study concedes that the period of the apparent decline in Nigeria's agricultural production coincided with that of the oilboom.

Specifically, the study aimed at the following objectives:

i. Compare pre-oilboom and oilboom periods capital expenditure allocation to the agriculture sector.

ii. Compare capital expenditure allocation to agriculture and water resources, health, education and defence sectors during the oilboom period (1977-83)

iii. Compare capital expenditure allocation to agriculture, health, education and defence sectors during the oilboom period (1977-83)

\section{Methodology}


Aggregate data on planned capital expenditure allocation to the agriculture sector in the four National development Plans: First (1962-68), Second (1970-74), Third (1975-1980) and fourth (1981-1985) were sourced. In addition, the budget estimates of capital expenditure allocations to the Agriculture, Water Resources, Health, Education and Defence sectors in Nigeria during the oil boom period 1977-1983, were collected from publications of the Central Bank of Nigeria. Descriptive statistics was used to achieve objective (i). The one-way analysis of variance technique was used to achieve objectives (ii) and (iii) (see Keller and Warrack, 2003 \& Snedecor and Cochran, 1980; for a description of this technique). The Tukey's Multiple Comparison method was employed to determine which mean(s) differ, in both cases, in the one-way analysis of variance tests conducted. The data collected for this study were analysed using SPSS 16.0.

The following hypotheses were formulated and tested:

i. There are no significant differences between the mean sectoral capital expenditure allocation to Agriculture and Water Resources, Health, Education and Defence in Nigeria during the oil boom period.

ii. There are no significant differences between the mean capital expenditure allocation to agriculture, health, education and defence sectors in Nigeria during the oil boom period.

\section{Results and Discussions}

\subsection{Capital Allocation to Agriculture in the Pre-Oilboom (1962-74) and the Oilboom (1975-85) Periods}

Figure 1 shows the volume of capital allocation to the agriculture sector before and during the oilboom periods. From the figure it is clear that the volume of capital allocation to the agriculture sector during the oilboom period was more than $1200 \%$ higher than that during the pre-oilboom period. This finding support the view that the oilboom relaxed the financial constraints to development (Sanyal and Babu, 2010), and made more funds available for agricultural development.

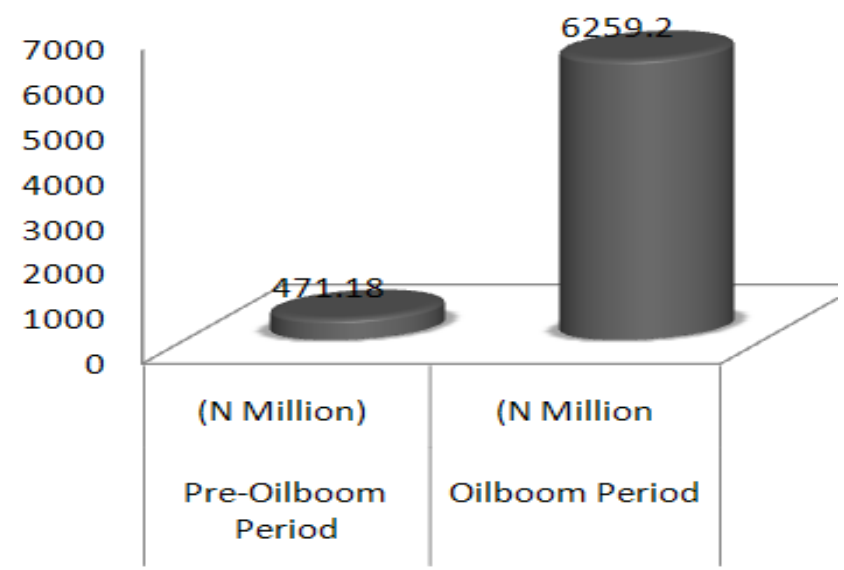

Figure 1. Capital allocation for agriculture in National Development Plans for the pre-oilboom and the oilboom periods. Source: see Appendix Table A1

\subsection{Capital Expenditure Allocation to Agriculture and Water Resources Relative to That of Health, Education and Defence Sectors in Nigeria during the Oilboom Period (1977-83)}

The value of the test statistic $\mathrm{F}=24.186$ and its corresponding p-value of 0.000 indicates a very strong statistical evidence (highly significant) to reject the null hypothesis and conclude that mean aggregate capital expenditure allocation differ in at least 3 of the 4 sectors under study.

Table 1. One-way ANOVA for sectoral capital expenditure allocations to agriculture \& water resources, health, education and defence during the oilboom period

\begin{tabular}{|c|c|c|c|c|c|}
\hline $\begin{array}{c}\text { Source Of } \\
\text { Variation }\end{array}$ & $\begin{array}{c}\text { Sum Of } \\
\text { Squares }\end{array}$ & Df & $\begin{array}{c}\text { Mean } \\
\text { Squares }\end{array}$ & F & Sig. \\
\hline $\begin{array}{c}\text { Between } \\
\text { Groups }\end{array}$ & $2.325 \mathrm{e} 7$ & 3 & 7749685.529 & 24.186 & 0.000 \\
\hline $\begin{array}{c}\text { Within } \\
\text { Groups }\end{array}$ & 7689943.520 & 24 & 320414.313 & & \\
\hline Total & $3.094 \mathrm{e} 7$ & 27 & & & \\
\hline
\end{tabular}

To determine which among the four sectors means differ in the one-way analysis of variance test conducted, the Tukey's Multiple Comparison method was employed. Results of the test indicate that the mean capital expenditure allocated to the agriculture and water resources sector is significantly higher than that allocated to either of Health, Education and Defence sectors in Nigeria over the oilboom period. In other words, much more resources were allocated as capital expenditure to the agriculture and water resoorces sector than to either of Health, Defence or Education sector.

Table 2. Tukey's Multiple Comparison for sectoral capital expenditure allocations to agriculture \& water resouces, health, education and defence during the oilboom period

\begin{tabular}{|c|c|c|c|c|}
\hline $\begin{array}{c}\text { Sector } \\
(\mathrm{I})\end{array}$ & $\begin{array}{c}\text { Sector } \\
(\mathrm{J})\end{array}$ & $\begin{array}{c}\text { Mean } \\
\text { Difference }(\mathrm{I}-\mathrm{J})\end{array}$ & $\begin{array}{c}\text { Standard } \\
\text { Error }\end{array}$ & Sig. \\
\hline \multirow{3}{*}{1} & 2 & $2196.02857^{*}$ & $3.0256 \mathrm{E} 2$ & 0.000 \\
& 3 & $1801.58571^{*}$ & $3.0256 \mathrm{E} 2$ & 0.000 \\
& 4 & $2211.94286^{*}$ & $3.0256 \mathrm{E} 2$ & 0.000 \\
\hline \multirow{3}{*}{2} & 1 & $-2196.02857^{*}$ & $3.0256 \mathrm{E} 2$ & 0.000 \\
& 3 & -394.44286 & $3.0256 \mathrm{E} 2$ & 0.570 \\
& 4 & 15.91429 & $3.0256 \mathrm{E} 2$ & 0.538 \\
\hline \multirow{3}{*}{3} & 1 & $-1801.58571^{*}$ & $3.0256 \mathrm{E} 2$ & 0.000 \\
& 2 & 394.44286 & $3.0256 \mathrm{E} 2$ & 0.570 \\
& 4 & 410.35714 & $3.0256 \mathrm{E} 2$ & 0.538 \\
\hline & 1 & $-2211.94286^{*}$ & $3.0256 \mathrm{E} 2$ & 0.000 \\
& 2 & -15.91429 & $3.0256 \mathrm{E} 2$ & 1.000 \\
& 3 & -410.35714 & $3.0256 \mathrm{E} 2$ & 0.538 \\
\hline
\end{tabular}

*Highly significant difference. Key: Agriculture and Water Resources (1); Health (2); Education (3); Defence (4).

\subsection{Capital Expenditure Allocation to Agriculture Relative to That of Health, Education and Defence Sectors in Nigeria during the Oilboom Period (1977-83)}

The figures for agriculture and water resources sector were decomposed and the test was repeated using capital expenditure figures of the agricultural sector alone. The value of the test statistic $\mathrm{F}=7.441$ and its corresponding $p$-value of 0.001 indicates a very strong statistical evidence 
(highly significant) to reject the null hypothesis and conclude that mean aggregate capital expenditure allocation differ in at least 3 of the 4 sectors under study.

Table 3. One-way ANOVA for sectoral capital expenditure allocations to agriculture, health, education and defence during the oilboom period

\begin{tabular}{|c|c|c|c|c|c|}
\hline $\begin{array}{c}\text { Source of } \\
\text { variation }\end{array}$ & $\begin{array}{c}\text { Sum of } \\
\text { squares }\end{array}$ & df & $\begin{array}{c}\text { Mean } \\
\text { squares }\end{array}$ & F & Sig. \\
\hline $\begin{array}{c}\text { Between } \\
\text { Groups }\end{array}$ & 1324098.093 & 3 & 441366.031 & 7.441 & 0.001 \\
\hline $\begin{array}{c}\text { Within } \\
\text { Groups }\end{array}$ & 1423629.617 & 24 & 59317.901 & & \\
\hline Total & 2747727.710 & 27 & & & \\
\hline
\end{tabular}

To determine which among the four sectors' means differ in the one-way analysis of variance test conducted, the Tukey's Multiple Comparison method was employed. Results of the test indicate that the mean capital expenditure allocated to the agricultural sector is significantly higher than that allocated to both the Health and Defence sectors during the oilboom period. However, the mean difference of more than 60 million Naira indicates that the mean capital expenditure allocation to the agriculture sector is slightly, though not statistically significant, higher than the mean capital expenditure allocation to the education sector during the oilboom period. Thus, more resources were allocated as capital expenditure to the agriculture sector than to either of Health, Defence or Education during the oilboom period.

Table 4. Tukey's Multiple Comparison for sectoral capital expenditure allocations to agriculture, health, education and defence during the oilboom period

\begin{tabular}{|c|c|c|c|c|}
\hline $\begin{array}{c}\text { Sector } \\
(\mathrm{I})\end{array}$ & $\begin{array}{c}\text { Sector } \\
(\mathrm{J})\end{array}$ & $\begin{array}{c}\text { Mean } \\
\text { Difference (I-J) }\end{array}$ & $\begin{array}{c}\text { Standard } \\
\text { Error }\end{array}$ & Sig. \\
\hline 1 & 2 & $454.97143^{*}$ & $1.3018 \mathrm{E} 2$ & 0.009 \\
& 3 & $60.52857^{*}$ & $1.3018 \mathrm{E} 2$ & 0.966 \\
& 4 & $470.88571^{*}$ & $1.3018 \mathrm{E} 2$ & 0.007 \\
\hline 2 & 1 & $-454.97143^{*}$ & $1.3018 \mathrm{E} 2$ & 0.009 \\
& 3 & $-394.44286^{*}$ & $1.3018 \mathrm{E} 2$ & 0.028 \\
& 4 & 15.91429 & $1.3018 \mathrm{E} 2$ & 0.999 \\
\hline 3 & 1 & -60.52857 & $1.3018 \mathrm{E} 2$ & 0.966 \\
& 2 & $394.44286^{*}$ & $1.3018 \mathrm{E} 2$ & 0.028 \\
& 4 & $410.35714^{*}$ & $1.3018 \mathrm{E} 2$ & 0.021 \\
\hline 4 & 1 & $-470.88571^{*}$ & $1.3018 \mathrm{E} 2$ & 0.007 \\
& 2 & 15.91429 & $1.3018 \mathrm{E} 2$ & 0.999 \\
& 3 & $410.35714^{*}$ & $1.3018 \mathrm{E} 2$ & 0.021 \\
\hline
\end{tabular}

*Significant at the 5\% level. Key: Agriculture (1); Health (2); Education (3); Defence (4).

The findings of this study indicate that governments in Nigeria have not neglected agriculture as a result of the oilboom. Oilboom period Nigerian governments have invested heavily in agricultural development through the establishment of the Nigerian Agricultural Bank in 1973; Integrated Agricultural Development Projects (ADPs), World Bank assisted in 1974; Operation Feed the Nation, 1976; Strenghthening of the River Basin Development Authorities (RBDAs) in 1977; Green Revolution in 1980; Accelerated Developmement Area Programme (ADA) in 1981; Livestock Development Programme (LDP) in 1981; Rural Agro-Industrial Scheme (RAIS) in 1981; and a running 75\% subsidy on fertilizer (1977-83). To furhter enhance the availability of formal credit to Nigerian farmers during the oilboom period government established the Rural Banking Programme and the Agricultural Credit Guarantee Scheme Fund both in 1977. Therefore, the decline in agricultural production in Nigeria could not be statistically attributed to the neglect of the agricultural sector resulting from oil boom. The reason could be as a manifestation of Dutch Disease (Jazayeri, 1986; Ebrahim-Zadeh, 2003; Olusi and Olagunju, 2005), Natural Resource Curse (Pinto, 1987; Gelb and Associates, 1988; Sala-i-Martin and Subramanian, 2003), Rent Seeking phenomenom (Lane and Tornell, 1999) or some other reason else.

\section{Conclusions}

This paper set out to statistically find answer to the question: following the oilboom in Nigeria, was agriculture really neglected? The study takes a historical perspective to trace the path of capital expenditure allocations to the agricultural sector in Nigeria. The empirical findings of the study indicate significant increase in the quantity of capital expenditure allocation to the agriculture sector during the oilboom period; and that more capital expenditure was allocated to the agriculture sector than was allocated to either of Health, Education or Defence sectors in Nigeria during the oilboom period. Thus, it can be concluded that, in terms of sectoral capital expenditure allocations, agriculture in Nigeria was not neglected as a result of oilboom. Therefore, the decline in agricultural production in Nigeria was not statistically attributable to neglect of the agricultural sector during the oil boom period. The reason could be as a manifestation of Dutch Disease, Natural Resource Curse, Rent Seeking phenomenom, or some other reason else.

\section{REFERENCES}

[1] Abdullahi, A. (1981). The Problems and Prospects of the Green Revolution for Agricultural and Rural Development of Nigeria: Technical and Environmental Perspectives. In Abalu, G.O.I., Abdullahi, Y. and Imam. A. M. (Eds). The Green Revolution in Nigeria? Proceedings of a National Seminar organised by the Department of Agricultural Economics and Rural Sociology, Ahmadu Bello University and held in Zaria, Nigeria from September 21st - 24th . pp 1-11

[2] Alamu, J. F. (1981). Small-Scale Mechanised Farming: The only Hope of the Current Green Revolution in Nigeria. In Abalu, G.O.I., Abdullahi, Y. and Imam. A. M. (Eds). The Green Revolution in Nigeria? Proceedings of a National Seminar organised by the Department of Agricultural Economics and Rural Sociology, Ahmadu Bello University and held in Zaria, Nigeria from September 21st - 24th . pp 132-139

[3] Asiabaka, C. C. and Owens, M. (2002). Determinants of Adoptive Behaviors of Rural Farmers in Nigeria. Proceedings of the 18th AIAEE Annual Conference Durban, South Africa. 
Pp13-20

[4] CBN (2007). Central Bank of Nigeria Statistical Bulletin Volume 18 Section B Public Finance Statistics. Abuja: Central Bank of Nigeria

[5] Chukwuemeka, E. and Nzewi, H. N. (2011). An empirical study of World Bank agricultural development programme in Nigeria. American Journal of Social and Management Sciences 2(1): 176-187

[6] Ebrahim-Zadeh, C. (2003). Dutch Disease: Too much Wealth Managed Unwisely. Finance and Development 40 1: 1-4

[7] FMANR (1974). Agricultural Development in Nigeria 1973-1985. Lagos: FMANR. 555p

[8] Forrest, T. G. (1980). Agricultural Policies in Nigeria 1900-1978. Rural underdevelopment in Nigeria 1900-1980. Department of Political Science Seminar Series Vol. 2. Zaria: ABU Press. Pp 1-20

[9] Garba, P. K. (2000). An analysis of the Implementation and Stability of Nigerian Agricultural Policies 1970-1993. AERC Research Paper 101. Nairobi: African Economic Research Consortium

[10] Gelb, A. and Associates (1988). Oil Windfalls: Blessing or Curse? World Bank: Oxford University Press

[11] Ilugbuhi, T. O. (1968). Nigeria's Experience in Domestic Financing of Development. Research Memo series. Zaria: Institute of Administration

[12] Izuchukwu, O. (2011). Analysis of the Contribution of Agricultural Sector on the Nigerian Economic Development. World Review of Business Research (1) 1: $191-200$

[13] Jazayeri, A. (1986). Prices and Output in Two Oil-based Economies: The Dutch Disease in Iran and Nigeria. IDS Bulletin (October) pp 14-21

[14] Keller, G. and Warrack B. (2003). Statistics for Management and Economics 6th Edition. Pacific Grove: Thomson Brooks/Cole.
[15] Lane, P. and Tornell, A. (1999). The Voracity Effect. American Economic Review 89: 22-46

[16] Okojie, C. (1991). Achieving Selfreliance in Food Production in Nigeria: Maximising the Contribution of Rural Women. Journal of Social Development in Africa 6 (2):33-52

[17] [Olusi, J. O. and Olagunju, M. A. (2005). The Primary Sectors of the Economy and the Dutch Disease in Nigeria. The Pakistan Development Review 44 2: 159-175

[18] Osuntogun, A., Edordu, C.C. and Oramah, B. O. (1997). Potentials for diversifying Nigeria's non-oil exports to non-traditional markets. AERC Research Paper 68. Nairobi: African Economic Research Consortium

[19] Pinto, B. (1987). Nigeria During and After the Oil Boom: A Policy Comparison with Indonesia. The World Bank Economic Review 1 (3): 419-445

[20] Reynolds, L. C. (1966). Peasant Agriculture and Economic Growth in Nigeria. The Economic Growth Center, Yale: Yale University

[21] Sala-i-Martin, X. and Subramanian, A. (2003). Addressing the Natural Resource Curse: An Illustration from Nigeria. Department of Economics Discussion Paper No: 0203-15. New York: Columbia University

[22] Sanyal, P. and Babu, S. (2010). Policy Benchmarking and Tracking the Agricultural Policy Environment in Nigeria. Nigeria Strategy Support Program (NSSP) Report No. NSSP 005. Abuja:IFPRI

[23] Sekumade, A. B. (2009). The effects of petroleum dependency on agricultural trade in Nigeria: An error correlation modeling (ECM) approach. Scientific Research and Essay 4 (11) : 1385-1391

[24] Snedecor, G. W., and Cochran, W. G. (1980). Statistical Methods, 7th edition. Ames: Iowa State University Press

[25] Walkenhorst, P. (2007). Distortions to Agricultural Incentives in Nigeria. Agricultural Distortions Working Paper 37. Washington DC: World Bank 